\title{
Evaluation of the MOZAIC Capacitive Hygrometer during the airborne field study CIRRUS-III
}

\author{
P. Neis ${ }^{1,3}$, H. G. J. Smit ${ }^{1}$, M. Krämer ${ }^{2}$, N. Spelten ${ }^{2}$, and A. Petzold ${ }^{1}$ \\ ${ }^{1}$ Forschungszentrum Jülich GmbH, Institut für Energie and Klimaforschung, IEK-8 Troposphäre, 52425 Jülich, Germany \\ ${ }^{2}$ Forschungszentrum Jülich GmbH, Institut für Energie and Klimaforschung, IEK-7 Stratosphäre, 52425 Jülich, Germany \\ ${ }^{3}$ Johannes Gutenberg Universität Mainz, Institut für Physik der Atmosphäre, 55099 Mainz, Germany \\ Correspondence to: P. Neis (p.neis@fz-juelich.de)
}

Received: 15 July 2014 - Published in Atmos. Meas. Tech. Discuss.: 22 September 2014

Revised: 18 December 2014 - Accepted: 9 February 2015 - Published: 13 March 2015

\begin{abstract}
The MOZAIC Capacitive Hygrometer (MCH) is usually operated aboard passenger aircraft in the framework of MOZAIC (Measurement of Ozone by Airbus In-Service Aircraft) for measuring atmospheric relative humidity (RH). In order to evaluate the performance of the $\mathrm{MCH}$, the instrument was operated aboard a Learjet 35A research aircraft as part of the CIRRUS-III field study together with a closed-cell Lyman- $\alpha$ fluorescence hygrometer (Fast in situ Stratospheric Hygrometer, or FISH) and an open-path tunable diode laser system (Open-path Jülich Stratospheric TDL ExpeRiment, or OJSTER) for water vapour measurement. After reducing the CIRRUS-III data set to data corresponding to MOZAIC aircraft operation conditions, the $1 \mathrm{~Hz} \mathrm{RH}$ data cross correlation between the $\mathrm{MCH}$ and reference instruments FISH (clear sky) and OJSTER (in-cirrus) yielded a remarkably good agreement of $R^{2}=0.92$ and slope $m=1.02$ and provided a $\mathrm{MCH}$ uncertainty of $5 \% \mathrm{RH}$. Probability distribution functions of $\mathrm{RH}$ deduced from the $\mathrm{MCH}$ and reference instruments agreed well between 10 and $70 \% \mathrm{RH}$ with respect to liquid water in the ambient temperature range of ca. -70 to $-40^{\circ} \mathrm{C}$. The use of $\mathrm{MCH}$ data is limited to sensor temperatures above the calibration limit of $T_{\text {sensor }}=-40^{\circ} \mathrm{C}$ (corresponds to ambient temperature of $T_{\text {ambient }}=-70^{\circ} \mathrm{C}$ at typical cruising speed of long-haul passenger aircraft). Good performance of the MCH for clear sky as well as for in-cirrus conditions demonstrated the sensor robustness also for operation inside ice clouds.
\end{abstract}

\section{Introduction}

Water vapour is one of the most important variables for weather prediction and climate research. Particularly, the interaction between the water vapour in the UT-LS (upper troposphere and lowermost stratosphere) and tropopause dynamics is not well understood. Thus, in the latest IPCC report (IPCC, 2013), it is stated that the knowledge about potential trends and climate feedback mechanisms of uppertropospheric water vapour is poor because of the lack of long data records of high quality in this specific region of the global atmosphere. Neither the global radiosonde network nor satellites can provide measurements of the required spatial and temporal resolution, while the regular in situ measurement of upper-tropospheric humidity (UTH) is still difficult.

Since 1994, the European research programme MOZAIC (Measurement of Ozone by Airbus In-Service Aircraft; Marenco et al., 1998) and its successor IAGOS (In-service Aircraft for a Global Observing System; Petzold et al., 2013) have been providing regular data for relative humidity (RH) and other meteorological quantities like temperature and pressure as well as data on atmospheric composition (e.g. ozone and $\mathrm{CO}$ ) with high spatial and temporal resolution on a global scale. The long-term observations are obtained by in situ measurements aboard civil passenger aircraft using the existing infrastructure of the international air transport system. However, the continuous high-quality in situ measurements are restricted to the major global flight routes and to the cruising altitude band of $9-13 \mathrm{~km}$; i.e. the observations refer to a large extent to the UT-LS region. Relative humidity 
data from the MOZAIC programme have been used for various climatological studies, including the distribution of UTH (Kley et al., 2007; Luo et al., 2007, 2008), the distribution of $\mathrm{RH}$ with respect to ice $\left(\mathrm{RH}_{\mathrm{ice}}\right.$; e.g. Gierens et al., 1997 , 1999) and ice-supersaturation regions (e.g. Gierens et al., 2000; Spichtinger et al., 2003) in the upper troposphere.

Atmospheric RH is measured in the MOZAIC/IAGOS programme through a compact airborne humidity sensing device using capacitive sensors (MOZAIC Capacitive Hygrometer: $\mathrm{MCH}$ ). The sensor itself and the applied calibration techniques are described in detail by Helten et al. (1998). The first validation studies from formation flights of a MOZAIC aircraft and a research aircraft are reported by Helten et al. (1999), while Smit et al. (2008) present an approach for a potential in-flight calibration of the $\mathrm{MCH}$. A reanalysis of the global MOZAIC RH data set for the period 2000-2009 was performed recently (Smit et al., 2014).

In order to assess the validity of the long-term water vapour data and their limitations, Helten et al. (1999) provided an in-flight comparison of MOZAIC and POLINAT (Schlager et al., 1997; Schumann, 1997) water vapour measurements. However, this formation flight intercomparison was difficult to analyse because the twin-engine research aircraft Falcon 20 had to follow the MOZAIC Airbus A340300 with changing time lags and distances whereby sampling of identical air masses can not always be ensured. In 2006, there was the opportunity to participate in the aircraft campaign CIRRUS-III along with high-precision researchgrade instruments for measuring the water vapour volume mixing ratio (VMR). The in-flight single-platform measurements permitted a blind intercomparison of the $\mathrm{MCH}$ with high-performance water vapour instruments by measuring the same air masses and under different atmospheric conditions. A similar analysis of the improved IAGOS Capacitive Hygrometer is in preparation and will be published elsewhere.

\section{MOZAIC Capacitive Hygrometer}

A detailed description of the MOZAIC Capacitive Hygrometer is given by Helten et al. $(1998,1999)$ and Smit et al. (2014). In the following, we summarise the original descriptions.

The compact airborne $\mathrm{MCH}$ consists of a capacitive sensor (Humicap-H, Vaisala, Finland) whose capacitance depends on the relative humidity of the dielectric layer of the condenser and a platinum resistance sensor (Pt100) for the direct measurement of the temperature at the humidity sensing surface. The basic measurement process is based on the diffusion-limited adsorption of the $\mathrm{H}_{2} \mathrm{O}$ molecules by the dielectric membrane of the sensor. Since diffusion is strongly temperature-dependent, the sensor response slows down with decreasing temperatures. Figure 1 shows how both sensors are mounted in the used air sampling hous-

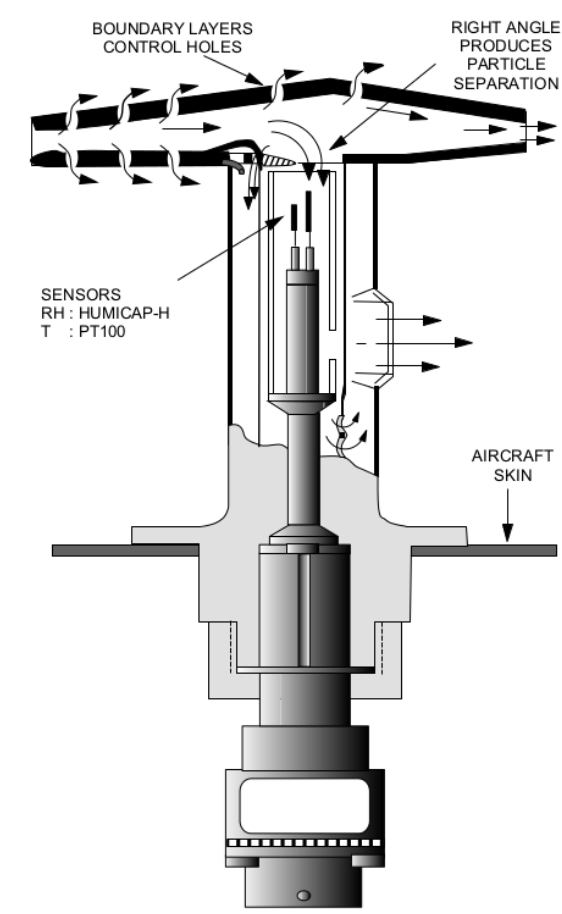

Figure 1. Cross section of the airborne capacitive sensing element. Right angle protects against particles, and control holes in the side wall minimise internal boundary layer effects (Helten et al., 1998).

ing (Model 102 BX, Rosemount Inc.; see Stickney et al., 1990). The relative humidity and temperature signals are fed into a microprocessor-controlled transmitter unit (HMP230, Vaisala) which passes the signals to the data acquisition system. The data conversion from capacitance signals to relative humidity values is performed offline in a separate data quality assurance and analysis step.

In its original MOZAIC mounting position aboard an Airbus A340-400 the sensor housing is placed ca. $7 \mathrm{~m}$ downstream of the aircraft nose on the left side with a $7 \mathrm{~cm}$ distance from the aircraft skin to avoid possible contaminating interferences of the aircraft skin. Inside the Rosemount housing the air flow is separated into the main flow, which traverses straight through the housing, and the minor flow, which follows a sharp right angle into a smaller channel where the sensors are placed. The housing is equipped with small holes in the side wall to neglect internal boundary layer effects by sucking the internal boundary layer air through the holes. The right angle of the minor flow protects the RH and $T$ sensors against dust, water and particles.

Due to the strong speed reduction in the inlet part of the housing, the sampled air flow is significantly heated through adiabatic heating. Assuming $100 \%$ conversion of kinetic energy into heat during flow deceleration, the ambient temperature $T_{\text {ambient }}$ (static air temperature, SAT) increases to the temperature at the sensor inside the housing, i.e. the sensor temperature $T_{\text {sensor }}$ (total air temperature, TAT). Given the 


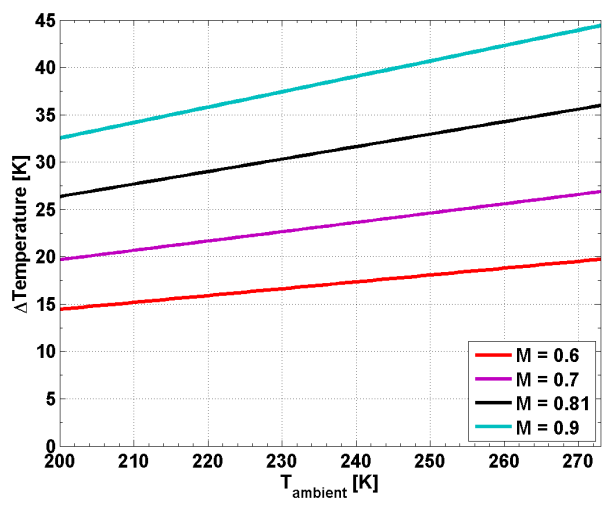

Figure 2. Sampled air flow is heated through adiabatic heating effects when entering the inlet. $\Delta$ Temperature describes the increase relative to the ambient temperature $T_{\text {ambient }}$ (static air temperature, SAT; see Helten et al., 1998) for several aircraft speeds, i.e. the Mach number $M$, by assuming $100 \%$ conversion of kinetic energy to heat during flow deceleration.

fact that the adiabatic conversion of energy is not exactly $100 \%$, the latter's quantity $\left(T_{\text {sensor }}\right)$ is calculated from the actually measured sensor temperature, i.e. the typically $0.1-$ $1.0 \mathrm{~K}$ colder recovery temperature (total recovery temperature, TRT), and the so-called recovery factor. This aircraftspeed-dependent and empirically determined factor is provided by the housing manufacturer.

The relationship between $T_{\text {ambient }}$ and $T_{\text {sensor }}$ is a function of the aircraft speed, i.e. its Mach number $M$ :

$T_{\text {sensor }}=T_{\text {ambient }} \cdot\left(1+\left(\frac{c_{p}-c_{v}}{2 c_{v}}\right) \cdot M^{2}\right)$,

where $c_{p}\left(=1005 \mathrm{~J} \mathrm{~kg}^{-1} \mathrm{~K}^{-1}\right)$ and $c_{v}\left(=717 \mathrm{~J} \mathrm{~kg}^{-1} \mathrm{~K}^{-1}\right)$ are the specific heat of dry air at constant pressure and volume, respectively. The resulting difference between $T_{\text {sensor }}$ and $T_{\text {ambient }}$ at $10-12 \mathrm{~km}$ cruising altitude for different Mach numbers is displayed in Fig. 2: for the MOZAIC-typical aircraft speed of $M=0.81$ the adiabatic heating effect is ca. $30 \mathrm{~K}$. $T_{\text {ambient }}$ is derived from Eq. (1) with an uncertainty of less than $\pm 0.5 \mathrm{~K}$ resulting from uncertainties in $T_{\text {sensor }}$ $( \pm 0.25 \mathrm{~K})$ and $M$. Because of the strong temperature increase, the detected dynamic relative humidity $\mathrm{RH}_{\text {dynamic }}$ is significantly lower than the static relative humidity $\mathrm{RH}_{\text {static }}$ of the ambient air at $T_{\text {ambient }}$ :

$$
\begin{aligned}
& \mathrm{RH}_{\text {static }}= \\
& \quad \mathrm{RH}_{\text {dynamic }} \cdot\left(\frac{T_{\text {ambient }}}{T_{\text {sensor }}}\right)^{\frac{c_{p}}{c_{p}-c_{v}}} \cdot \frac{e_{\text {s,liquid }}\left(T_{\text {sensor }}\right)}{e_{\mathrm{s}, \text { liquid }}\left(T_{\text {ambient }}\right)},
\end{aligned}
$$

where $e_{\text {s,liquid }}$ is the water vapour saturation pressure over liquid water at $T_{\text {sensor }}$ and $T_{\text {ambient }}$, respectively. The water vapour saturation pressure over liquid water $e_{\mathrm{s} \text {,liquid follows }}$ the Goff and Gratch (1946) formulation of saturation water vapour pressure over a plane surface of pure water or ice, which was recommended by the World Meteorological Organization (WMO, 1983) and adapted to the international temperature scale 1990 (ITS-90) by Sonntag (1994). For fast, high-flying aircraft the relation $\mathrm{RH}_{\text {static }} / \mathrm{RH}_{\text {dynamic }}$ reaches a factor of ca. 13, which leads to the fact that the RH sensor operates in the lowest $10 \%$ of its full dynamic range. Since the sensor is operating in the lower part of its full dynamic range, an individual calibration of each sensor is necessary, which is accomplished in the atmospheric simulation chamber at Jülich (Smit et al., 2000) before installation on the aircraft and after detachment past $500 \mathrm{~h}$ of flight. This corresponds to about 4-6 weeks between installation and deinstallation. These calibrations are made over a sensor temperature range between -40 and $+20^{\circ} \mathrm{C}$ against (i) a Lyman- $\alpha$ fluorescence hygrometer (Kley and Stone, 1978) at water vapour mixing ratios below $1000 \mathrm{ppmv}$ (relative accuracy $\pm 4 \%$, Helten et al., 1998) and (ii) a dew/frost point hygrometer (General Eastern, Type D1311R) at water vapour mixing ratios above 1000 ppmv with an accuracy of $\pm 0.5 \mathrm{~K}$. The relative humidity of a calibrated sensor $\left(\mathrm{RH}_{\mathrm{C}}\right)$ at constant temperature $T$ is found to be linearly related to the uncorrected output value ( $\mathrm{RH}_{\mathrm{UC}}$ ) provided by the HMP230 transmitter unit.

$\mathrm{RH}_{\mathrm{C}}(T)=a(T)+b(T) \cdot \mathrm{RH}_{\mathrm{UC}}(T)$

In Sect. 3.2 the calibration procedure of the $\mathrm{MCH}$ is described which was used during the CIRRUS-III field study. It combines the standard procedure based on Helten et al. (1998) and the in-flight calibration described by Smit et al. (2008).

Evaluation of 9 years of pre- and post-flight calibrations in MOZAIC has shown that the offset $a(T)$ is the most critical parameter in determining the uncertainty of the measurements with a shift of about $-5 \% \mathrm{RH}$, while the sensitivity (slope) $b(T)$ is less critical and only changes by about $-2 \%$.

\section{Experimental section}

\subsection{The CIRRUS-III field campaign}

To extend the performance assessment of the $\mathrm{MCH}$ from the formation flight intercomparison (Helten et al., 1999), the sensor was operated aboard a Learjet 35A twin-engine business-jet aircraft as part of the CIRRUS-III field study, which was coordinated by Forschungszentrum Jülich.

The overarching goals of CIRRUS-III were to understand the formation mechanism of cirrus clouds in different background conditions, their radiative effects and the microphysical properties of the cirrus cloud particles. In total six flights were conducted in the period between 23 and 29 November 2006 at mid-latitudes (45-70 N; see Fig. 3) and at flight altitudes between 7 and $12 \mathrm{~km}$. These flights in the UT-LS were launched from the Hohn Air Base in northern Germany with the Learjet 35A operated by enviscope $\mathrm{GmbH}$. 
Table 1. CIRRUS-III flight overview at cruise altitude. Air masses are divided into "troposphere" and "stratosphere" with the ozone VMR threshold of 125 ppmv.

\begin{tabular}{|c|c|c|c|c|c|c|}
\hline $\begin{array}{c}\text { Flight } \\
\text { no. }\end{array}$ & Date & $\begin{array}{l}\text { Take-off/ } \\
\text { landing (UTC) }\end{array}$ & $\begin{array}{l}\text { Temperature } \\
\text { range }\end{array}$ & $\begin{array}{l}\mathrm{H}_{2} \mathrm{O} \text { VMR } \\
\text { range }\end{array}$ & $\begin{array}{l}\text { In/out of } \\
\text { cirrus }\end{array}$ & $\begin{array}{l}\text { Stratosphere/ } \\
\text { troposphere }\end{array}$ \\
\hline 1 & $24 \mathrm{Nov}$ & $10: 47 / 14: 53$ & -62.6 to $-52.8^{\circ} \mathrm{C}$ & 24-107 ppmv & $95 / 96 \mathrm{~min}$ & $2 / 190 \mathrm{~min}$ \\
\hline 2 & $28 \mathrm{Nov}$ & $08: 22 / 12: 07$ & -62.4 to $-44.1^{\circ} \mathrm{C}$ & $17-138 \mathrm{ppmv}$ & $4 / 160 \mathrm{~min}$ & $11 / 153 \mathrm{~min}$ \\
\hline 3 & $28 \mathrm{Nov}$ & $13: 31 / 17: 25$ & -60.0 to $-42.4^{\circ} \mathrm{C}$ & $27-360 \mathrm{ppmv}$ & $56 / 124 \mathrm{~min}$ & $5 / 175 \min$ \\
\hline 4 & $29 \mathrm{Nov}$ & 09:16/13:51 & -61.2 to $-45.8^{\circ} \mathrm{C}$ & $16-216 \mathrm{ppmv}$ & $62 / 158 \mathrm{~min}$ & $2 / 218 \min$ \\
\hline Sum & & & -62.6 to $-42.4^{\circ} \mathrm{C}$ & $16-360 \mathrm{ppmv}$ & $217 / 537 \mathrm{~min}$ & $19 / 735 \mathrm{~min}$ \\
\hline
\end{tabular}

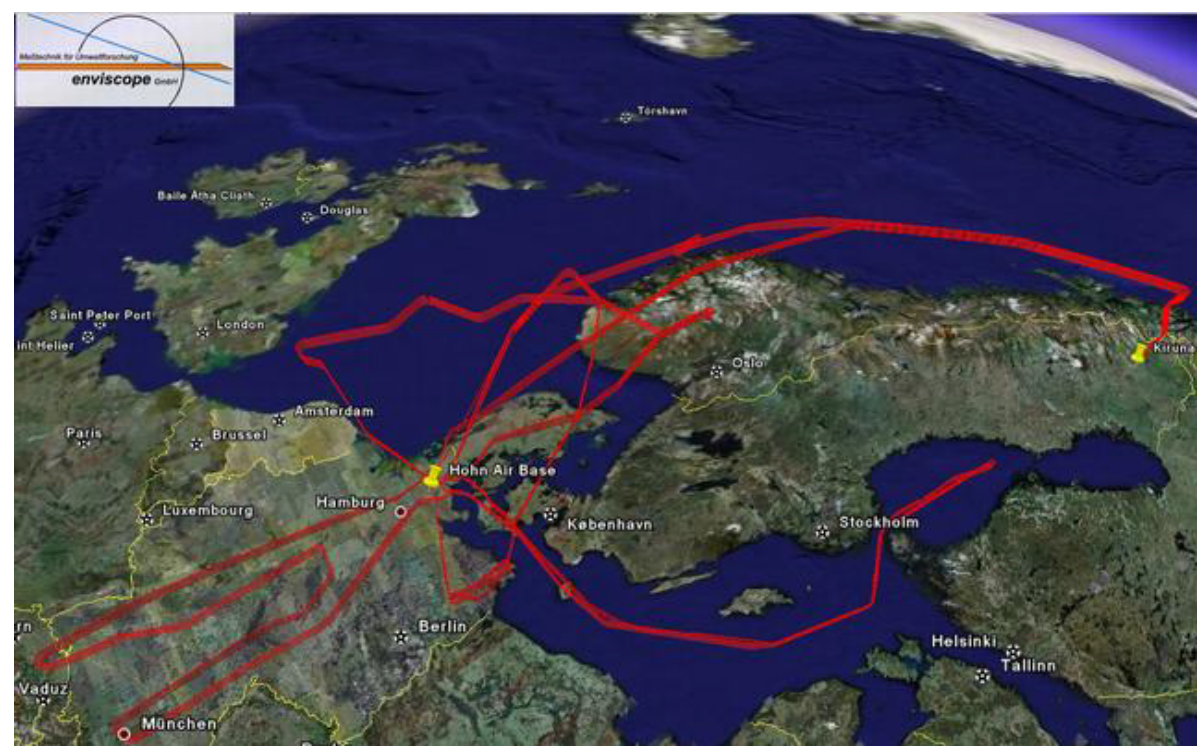

Figure 3. CIRRUS-III flight track overview (map data ${ }^{\circledR} 2008$ Google, Sanborn).

For the sensor intercomparison studies CIRRUS-III provided 4 flights (see Table 1). The data set consists of ca. 13 flight hours in air masses colder than $-40^{\circ} \mathrm{C}$ at cruise altitude, ca. 4 flight hours in cirrus clouds and 9 flight hours out of clouds. Furthermore, stratospherically influenced air masses were sampled for 19 min with ozone VMR above 125 ppmv, measured by the dual-beam UV-absorption ozone photometer JOE (Jülich Ozone Experiment) (Mottaghy, 2001). Two flights had to be discarded due to inlet heating problems at the reference instrument FISH (Fast in situ Stratospheric Hygrometer). An overview of the individual flights is provided in Table 1.

\subsection{Instrumentation}

During the CIRRUS-III field campaign, high-precision research-grade instruments were operated aboard the aircraft to characterise the air masses probed during flight patterns in frontal cirrus clouds. An important part of the instrumentation was dedicated to the measurement of gas-phase and total water. The instrumentation included a $\mathrm{MCH}$ and an open- path tunable diode laser (TDL) system (Open-path Jülich Stratospheric TDL ExpeRiment, OJSTER; MayComm Instruments, May and Webster, 1993; Krämer et al., 2009) to measure gas-phase water vapour VMR. Simultaneously, total water VMR (i.e. gas-phase plus ice water) was measured by the reference measurement instrument FISH (Zöger et al., 1999). The closed-cell Lyman- $\alpha$ fluorescence hygrometer was equipped with a forward-facing inlet to sample gasphase water in clear sky and total water inside cirrus clouds. To determine whether a data point is in a cirrus cloud or not, the ratio of $\mathrm{RH}_{\text {ice }}$ from FISH (total water) and OJSTER (water vapour) was used (see Krämer et al., 2009). FISH was calibrated using a laboratory calibration facility with the capability to simulate realistic atmospheric conditions, i.e. water vapour VMR from several hundred to a few ppmv and pressure from 1000 to $10 \mathrm{hPa}$. During the calibration, the water vapour mixing ratio was determined using a commercial dew point hygrometer (MBW DP30). The instruments and the parameters derived from their measurements are listed in Table 2. 
Table 2. Instruments and parameters used during the CIRRUS-III field campaign.

\begin{tabular}{|c|c|c|c|c|c|}
\hline Instrument & $\begin{array}{l}\text { Detection } \\
\text { quantity }\end{array}$ & $\begin{array}{l}\text { Measurement } \\
\text { technique }\end{array}$ & $\begin{array}{l}\text { Response } \\
\text { time }\end{array}$ & Uncertainty & Reference \\
\hline FISH & $\begin{array}{l}\text { VMR } \\
\text { [ppmv] }\end{array}$ & $\begin{array}{l}\text { Lyman- } \alpha \text { fluores- } \\
\text { cence hygrometer }\end{array}$ & $1 \mathrm{~s}$ & $\begin{array}{l}7 \% \pm 0.3 \mathrm{ppmv} \\
\text { (precision } 1 \% \text { ) }\end{array}$ & Zöger et al. (1999) \\
\hline OJSTER & $\begin{array}{l}\text { VMR } \\
\text { [ppmv] }\end{array}$ & Open-path TDL & $1 \mathrm{~s}$ & $10-15 \%$ & May and Webster (1993) \\
\hline $\mathrm{MCH}$ & $\begin{array}{l}\mathrm{RH}_{\text {liquid }} \\
{[\% \mathrm{RH}]}\end{array}$ & Capacitive sensor & $\begin{array}{l}\text { LT: } 1 \mathrm{~s}, \mathrm{UT}: 10 \mathrm{~s} \\
\text { LS: } 1 \mathrm{~min}\end{array}$ & $\begin{array}{l} \pm(4-7) \% \mathrm{RH} @ 10-13 \mathrm{~km} \\
\text { below } 10 \mathrm{~km} \pm(4-6) \% \mathrm{RH}\end{array}$ & Helten et al. (1998) \\
\hline
\end{tabular}

FISH: Fast in situ Stratospheric Hygrometer; OJSTER: Open-path Jülich Stratospheric TDL ExpeRiment; MCH: MOZAIC Capacitive Hygrometer; LT: lower troposphere; UT: upper troposphere; LS: lower stratosphere; for further information see Bange et al. (2013).

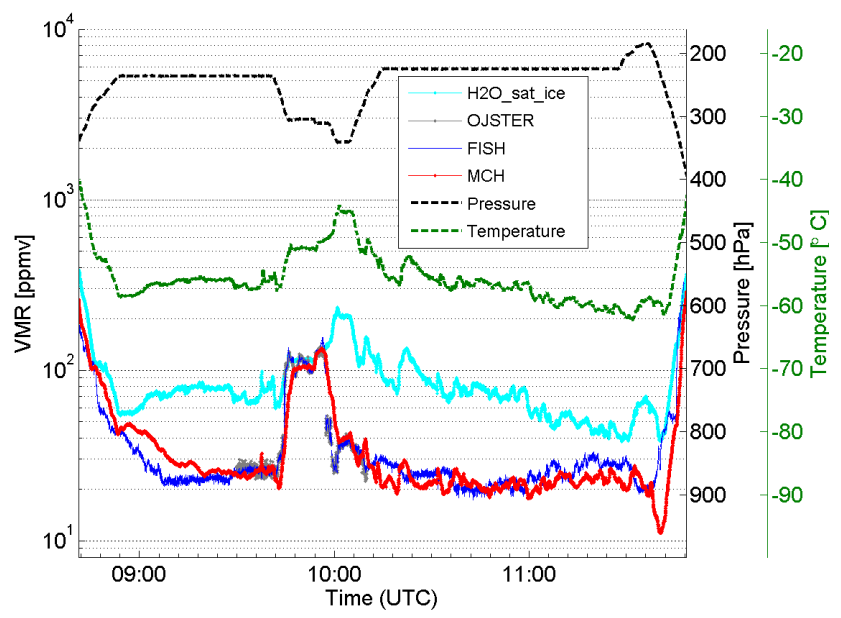

Figure 4. Time series of water vapour volume mixing ratio (VMR) from MCH (red), FISH (blue) and OJSTER (grey) during the CIRRUS-III flight on 28 November 2006. Ice saturation is shown in cyan, while pressure (black) and ambient air temperature (green) are plotted with dashed lines.

Prior to the CIRRUS-III campaign the $\mathrm{MCH}$ were (pre-flight) calibrated in the simulation chamber at Forschungszentrum Jülich following the procedures briefly described in Sect. 2. Unfortunately a post-flight calibration was not possible due to sensor failure after deinstallation of the $\mathrm{MCH}$ from the Learjet aircraft at the end of the campaign. From long-term experiences of MOZAIC preand post-flight calibrations it is well known that over the 3-month period between the pre-flight calibration and the end of the campaign the offset $a(T)$ can change significantly by about $5 \% \mathrm{RH}$ while the slope $b(T)$ changes by less than $2 \%$ on the relative scale (see Eq. 3 and Smit et al., 2014). In order to determine the potential change of the offset $a(T)$ between pre-flight calibration and the end of the campaign, the so-called in-flight calibration method (Smit et al., 2008) was applied.

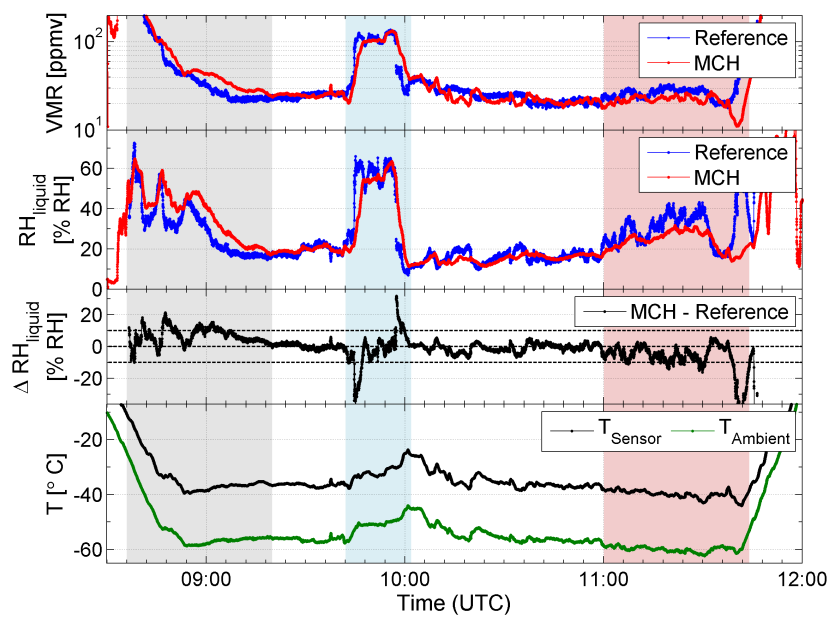

Figure 5. From top to bottom: VMR measured by the MCH (red) and the reference (blue), i.e. FISH (clear sky) and OJSTER (incirrus); $\mathrm{RH}_{\text {liquid }}$ and $\triangle \mathrm{RH}_{\text {liquid }}(\mathrm{MCH}$ and reference), as a function of flight time during flight 2 on 28 November 2006; and sensor temperature $T_{\text {sensor }}$ (black) as well as ambient temperature $T_{\text {ambient }}$ (green). The blue-shaded area represents air masses with high humidity and possible cirrus cloud. Air masses with sensor temperatures at and below the calibration limit are shaded in red. The greyshaded sequence illustrates the effect of increasing response time as sensor temperatures decrease.

Thus, the sensor offset $a(T)$ at lowest relative humidity was determined from the measurements themselves as obtained during periods of the aircraft flying in the lower stratosphere, where the water vapour mixing ratio reached well-defined minimum values. In our case, the minimum value in stratospherically influenced air masses was about $20 \pm 1$ ppmv as measured by the FISH instrument. Its resulting contribution to the $\mathrm{RH}_{\text {liquid }}$ signal of the $\mathrm{MCH}$ is minimal. Compared to the pre-flight calibration an offset change of $(4.5 \pm 1) \% \mathrm{RH}_{\text {liquid }}$ was found. The $\mathrm{RH}_{\text {liquid }}$ flight data of the $\mathrm{MCH}$ obtained during the CIRRUS-III campaign were corrected for this offset drift. The resulting overall uncertainty of the $\mathrm{RH}$ measurements by the $\mathrm{MCH}$, including contributions from temperature uncertainties, is about $\pm 5 \%$ 


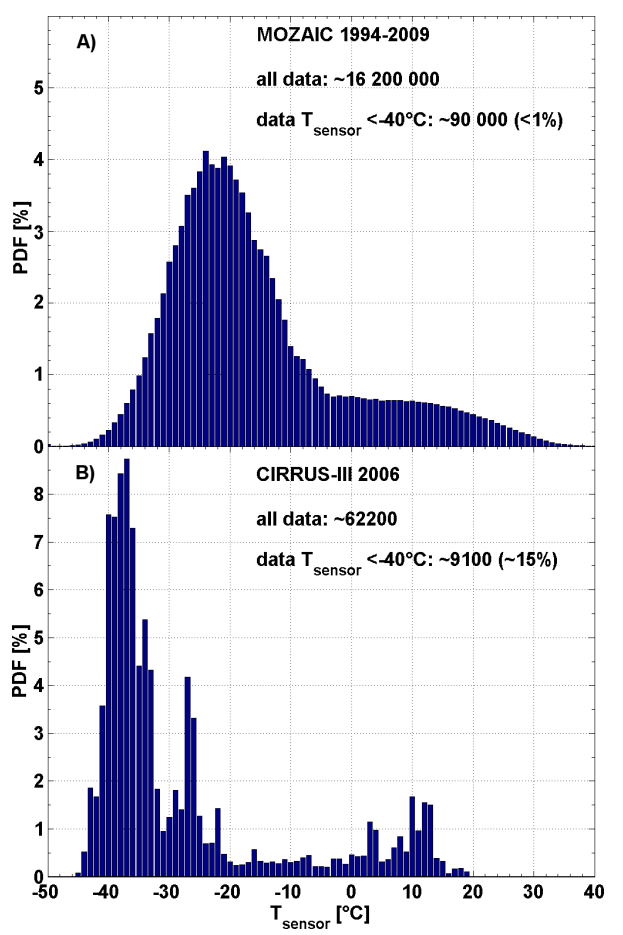

Figure 6. Frequency of occurrence for observations of $T_{\text {sensor }}$ during ca. 15 years of MOZAIC (top panel) and CIRRUS-III (bottom panel).

$\mathrm{RH}_{\text {liquid, }}$, which is in good agreement with the mean uncertainty range obtained from long-term MOZAIC measurements (Smit et al., 2014) .

\section{Results - assessment of MCH performance}

The instrumentation deployed in CIRRUS-III allows an inflight intercomparison of all water vapour instruments. Figure 4 illustrates an example of the kind of data collected from one research flight on 28 November 2006 (Flight 2). Data from the water vapour sensing instruments used for the intercomparison are shown as VMR. The $T_{\text {ambient }}$ encountered during the flight ranged from -44.1 to $-62.4^{\circ} \mathrm{C}$ for relevant measurement altitudes. The respective water vapour VMR covered the range from $17 \mathrm{ppmv}$ at the tropopause to ca. $150 \mathrm{ppmv}$ in the free troposphere and even higher values during ascent from and descent into the airport.

For the instrument intercomparison we analysed the sensors with respect to $\mathrm{RH}_{\text {liquid }}$ since this is the parameter the $\mathrm{MCH}$ is calibrated against in the sensor temperature range (see Sect. 2). Further, data for water vapour VMR $>1000$ ppmv were excluded from this study because the FISH instrument becomes optically opaque and thus insensitive to changes in VMR (Zöger et al., 1999).

In Fig. 5, we compare VMR data and $\mathrm{RH}_{\text {liquid }}$ data from the $\mathrm{MCH}$ and gas-phase reference, i.e. OJSTER data in cloud
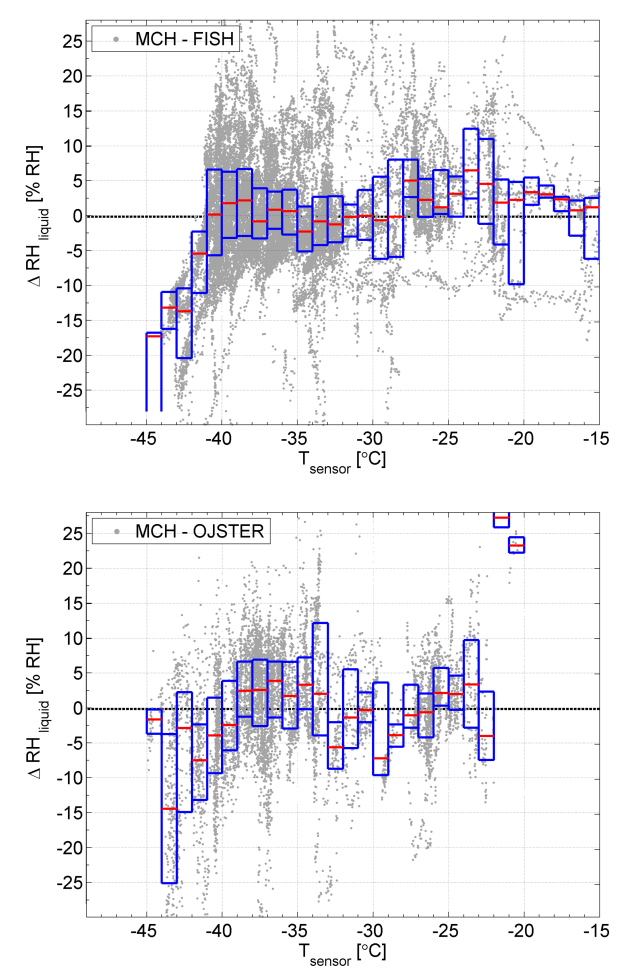

Figure 7. Differences in relative humidity $\mathrm{RH}_{\text {liquid }}$ of $\mathrm{MCH}$ and both reference instruments, i.e. FISH (top panel, clear sky) and OJSTER (bottom panel, in-cirrus), are scattered against the sensor temperature $T_{\text {sensor. }}$ A drift towards too-dry $\mathrm{MCH}$ measurements below the calibration limit of $-40^{\circ} \mathrm{C}$ is clearly seen. The median values (red lines in the box) of the $1^{\circ} \mathrm{C}$ binned data as well as the 25 th and 75 th percentiles are within the calibration limits.

or otherwise FISH data, for a complete validation of the $\mathrm{MCH}$ for flight 2. Largest deviations of the MCH to the reference are found in clear-sky air masses for cold conditions with $T_{\text {sensor }}<-40^{\circ} \mathrm{C}$ (this corresponds to ambient temperature below ca. $-60^{\circ} \mathrm{C}$ at $M=0.70$ ) and at transition sequences around the cirrus cloud. Except for these extreme conditions, the difference between the $\mathrm{MCH}$ and the reference is of the order of $10 \% \mathrm{RH}_{\text {liquid }}$ or less. Given the fact that during CIRRUS-III the MCH was operated at its lower limit of performance, the agreement with the research-grade reference instruments is remarkably good.

An analysis of $\mathrm{MCH}$ performance at the limit of its operation range is provided in the example of flight 2 in Sect. 4.2.

\subsection{MCH performance against reference instruments}

In order to prepare a data set for evaluation of the $\mathrm{MCH}$ performance, we introduced three filter operations to reduce the CIRRUS-III data set to MOZAIC typically operational conditions. First, it has to be noted that regular operation conditions of the $\mathrm{MCH}$ aboard long-haul passenger aircraft with a cruising speed of ca. $M=0.81$ are characterised by $T_{\text {sensor }} \geq-35^{\circ} \mathrm{C}$ (see Fig. 6a), which is within the 

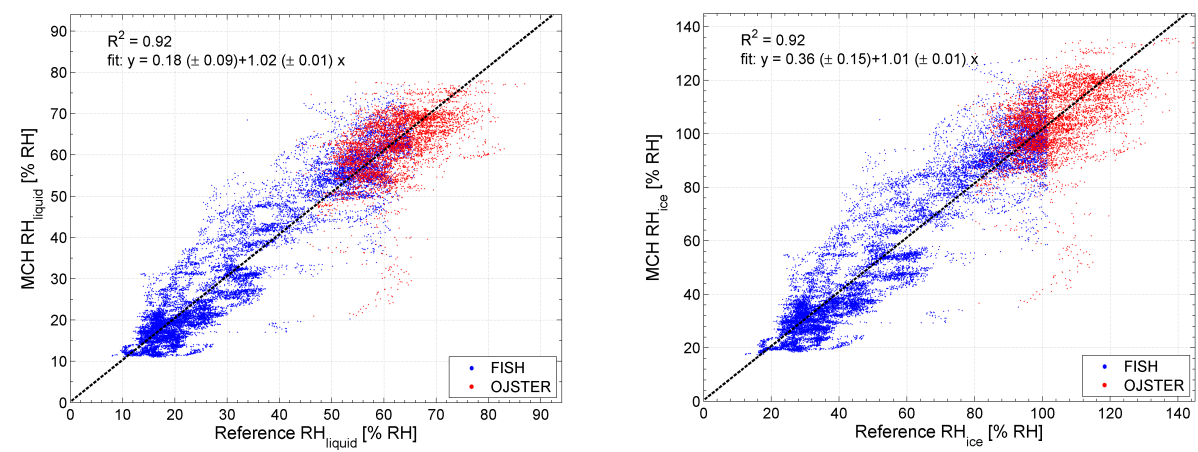

Figure 8. Comparison cross plot between reference, i.e. FISH (blue dots, clear sky) and OJSTER (red dots, in-cirrus), and MCH RH $\mathrm{Miquid}$ (left panel) and $\mathrm{RH}_{\mathrm{ice}}$ (right panel) each displayed as a scatter plot with robust fitting curve (dashed line).

lower $\mathrm{MCH}$ calibration limit of $-40^{\circ} \mathrm{C}$ (see Sect. 2). However, during the operation aboard the slower-flying Learjet $35 \mathrm{~A}$ (cruising speed $<M=0.70$ ), $T_{\text {sensor }}$ values significantly lower than $-40^{\circ} \mathrm{C}$ were reached (see Fig. 6b).

Consequently, data with $T_{\text {sensor }}<-40^{\circ} \mathrm{C}$ were excluded from the analysis. This fact is illustrated in Fig. 7, which shows the difference in $\mathrm{RH}_{\text {liquid }}$ between $\mathrm{MCH}$ and FISH data for clear-sky conditions and OJSTER data for in-cirrus conditions, according to $T_{\text {sensor }}$. Furthermore, the maximum $T_{\text {ambient }}$ was set to the level of instantaneous freezing of $-40{ }^{\circ} \mathrm{C}$ in order to minimise the perturbation of measurements by erroneously sampled liquid water droplets in warm clouds.

Finally, flight sequences of the Learjet $35 \mathrm{~A}$ with steep ascents and descents were excluded, since these flight conditions are not comparable to conditions aboard long-haul passenger aircraft. To obtain information about the $\mathrm{MCH}$ performance relevant for the MOZAIC data set, i.e. for nearly constant flight levels with moderately slow changes in temperature and humidity, the flight altitude for CIRRUS-III was smoothed over $90 \mathrm{~s}$ time intervals, and when altitude changes exceeded $\Delta z>6 \mathrm{~m}$ in $5 \mathrm{~s}$ the respective data points were excluded from the intercomparison. These filtering operations lead to a data set with MOZAIC typically operational conditions with a remaining fraction of about $36 \%$ of campaign data (see Table 3 for more details).

The correlation between $\mathrm{MCH}$ and reference $\mathrm{RH}_{\text {liquid }}$ data and $\mathrm{RH}_{\text {ice }}$ data from FISH (clear sky) and OJSTER (incirrus) is shown in Fig. 8. The scatter plots for the $1 \mathrm{~Hz}$ data sets reduced to MOZAIC-relevant conditions (hereafter referred to as "reduced data set") show similar scattering around the line of unity. Linear regression analysis confirms this with similar results for both cases: a correlation coefficient of $R^{2}=0.92$ with a slope of virtually unity. The offset for the $\mathrm{RH}_{\text {liquid }}$ regression is $0.18 \pm 0.09 \% \mathrm{RH}_{\text {liquid }}$, and for the $\mathrm{RH}_{\text {ice }}$ regression it is $0.36 \pm 0.15 \% \mathrm{RH}_{\text {ice }}$.

A more statistically based view on the data set is shown in Fig. 9, where the correlation between the sensors averaged for $5 \% \mathrm{RH}_{\text {liquid }}$ bins is shown. The $\mathrm{MCH}$ agrees very

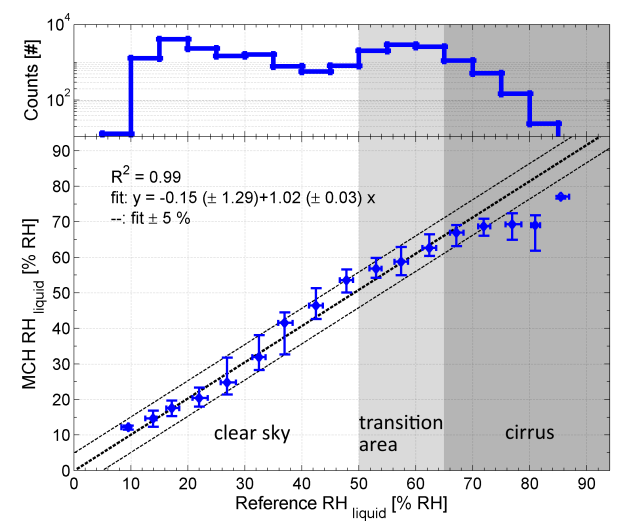

Figure 9. Correlation of $\mathrm{RH}_{\text {liquid }}$ data from $\mathrm{MCH}$ and the reference, i.e. FISH (clear sky) and OJSTER (in-cirrus), during CIRRUS-III; the straight line indicates the linear regression line, while the dashed lines illustrate the sensor uncertainty range $\pm 5 \% \mathrm{RH}_{\text {liquid. }}$ In the transition area both reference instruments can occur (see Fig. 8). The top panel shows the number of data points per $5 \% \mathrm{RH}_{\text {liquid }}$ bin.

well with the reference instruments over the entire range of values measured in the cloud-free atmosphere. Inside cirrus clouds, i.e. $\mathrm{RH}_{\text {liquid }}>$ ca. $70 \%$, the sensors deviate as expected as a result of the increased response time of the MCH. Small-scale supersaturations are smoothed out, while OJSTER can detect these with response time of ca. $1 \mathrm{~s}$. Linear regression analysis weighted with the number of occurrences provides a correlation coefficient of $R^{2}=0.99$ with an offset of $-0.15 \pm 1.29 \% \mathrm{RH}_{\text {liquid }}$ and a slope of $1.02 \pm 0.03$. Median values and almost all of the 25th and 75 th percentiles fall within the $\pm 5 \% \mathrm{RH}_{\text {liquid }}$ range around the linear regression line, which confirms the previously determined $\mathrm{MCH}$ uncertainty of $5 \% \mathrm{RH}_{\text {liquid }}$ (see also Table 4).

For a better understanding of an uncertainty of $5 \%$ $\mathrm{RH}_{\text {liquid }}$, Fig. 10 shows water vapour VMR as a function of temperature for $5 \%$ and $10 \% \mathrm{RH}_{\text {liquid }}$ for pressure levels at typical passenger aircraft flight altitudes. As an example, at $T_{\text {ambient }}=215 \mathrm{~K}$ and pressure $=220 \mathrm{hPa}$, a mea- 
Table 3. Fraction of remaining data after filtering the data set of MOZAIC atypically operational conditions.

\begin{tabular}{lll}
\hline Method & $\begin{array}{l}\text { Remaining } \\
\text { data }\end{array}$ & $\begin{array}{l}\text { Fraction of } \\
\text { remaining data }\end{array}$ \\
\hline No filter & 62207 & $100 \%$ \\
$T_{\text {ambient }}<-40^{\circ} \mathrm{C}$ & 35650 & $57 \%$ \\
$T_{\text {sensor }}>-40^{\circ} \mathrm{C}$ & 31331 & $50 \%$ \\
W/o ascent $/$ descent & 26234 & $42 \%$ \\
\hline All & 22184 & $36 \%$ \\
\hline
\end{tabular}

sured $\mathrm{RH}_{\text {liquid }}=5 \%$ with an uncertainty of $5 \% \mathrm{RH}_{\text {liquid }}$ corresponds to a VMR of ca. $5 \pm 5$ ppmv.

The consistency of the $\mathrm{MCH} \mathrm{RH}_{\text {liquid }}$ data is shown in Fig. 11. The probability distribution functions (PDFs) for $\mathrm{RH}_{\text {liquid }}$ derived from $\mathrm{MCH}$ data agree very well with those derived from the reference for the entire data set. Larger deviations at higher values of $\mathrm{RH}_{\text {liquid }}$, e.g. at possible cirrus cloud edges, reflect the fact of the longer response time of the $\mathrm{MCH}$. The sensor behaviour for those conditions at the limit of the sensor operation specifications is analysed in detail in the following section.

\subsection{Limits of MCH operation}

The comparison between the $\mathrm{MCH} \mathrm{RH}_{\text {liquid }}$ data and the reference $\mathrm{RH}_{\text {liquid }}$ data, i.e. OJSTER data in cloud or otherwise FISH data, during the CIRRUS-III field study shows a remarkably good agreement for the reduced data set. However, the performance of the MCH sensor in conditions at its limits of operation, e.g. close to the lower calibration limit of $T_{\text {sensor }}=-40^{\circ} \mathrm{C}$ or during strong humidity changes, has to be analysed in detail in order to assess the sensor's operation range. For this purpose, the time series of flight 2 is revisited in Fig. 5, where the individual $\mathrm{RH}_{\text {liquid }}$ time series, the difference of both $\mathrm{RH}_{\text {liquid }}$ time series and the $T_{\text {ambient }}$ as well as the $T_{\text {sensor }}$ time series are applied.

The following three sequences of interest have to be analysed:

- Sequence 1 lasts from 08:40 to 09:10 UTC, when the $\mathrm{MCH}$ still shows a good response at higher sensor temperatures of about $-20^{\circ} \mathrm{C}$ and agrees within $5-10 \%$ $\mathrm{RH}_{\text {liquid }}$ with the reference. However, at decreasing sensor temperature, the response time of the $\mathrm{MCH}$ increases significantly. This results in a delay causing higher humidity values and greater differences in the comparison with the reference. Because of the dominating van der Waals forces the adsorption of new water molecules by the dielectric membrane of the sensor occurs faster than desorption. For that, the response to positive humidity gradient is faster than to negative gradient, which can be seen in the behaviour of the $\mathrm{RH}_{\text {liquid }}$ differences in time.

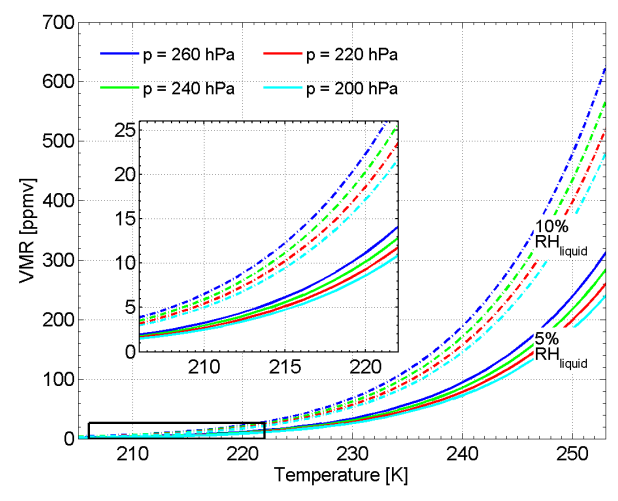

Figure 10. Water vapour volume mixing ratio (VMR) as a function of ambient temperature for $5 \%$ (solid lines) and $10 \% \mathrm{RH}_{\text {liquid }}$ (dashed lines), respectively. The different pressure levels represent typical passenger aircraft flight altitudes. The inner box shows a zoom of the lower temperature and VMR values.

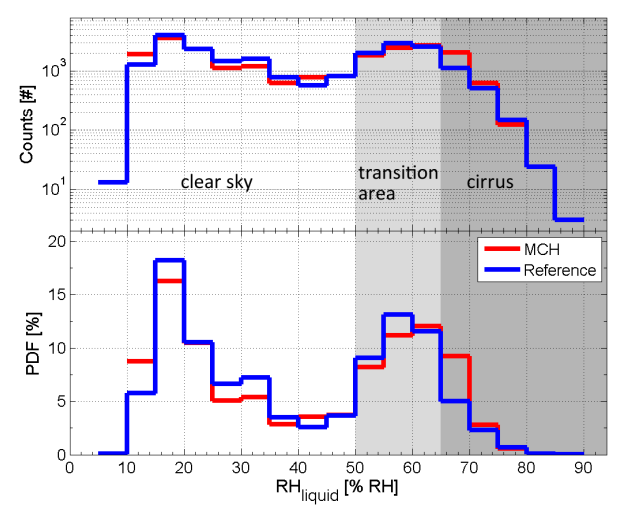

Figure 11. Number of data points (top panel) and frequency of occurrence (bottom panel) for observations of $\mathrm{RH}_{\text {liquid }}$ during CIRRUS-III; blue and red lines refer to data from reference, i.e. FISH (clear sky) and OJSTER (in-cirrus), and $\mathrm{MCH}$, respectively. The number of counts of both data sets agrees in almost all $5 \%$ $\mathrm{RH}_{\text {liquid }}$ bins. The exponential decline at higher values is in accordance with the result of Spichtinger et al. (2003). A bimodal distribution can be seen clearly in the probability density function (PDF) view of the data sets, where there is a clear-sky section at lower values and a cirrus section at higher values. The differences in the PDF can be mainly explained by the longer response time of the $\mathrm{MCH}$ into and out of the clouds.

- Sequence 2 illustrates a strong humidity change between 09:40 and 10:00 UTC, while flying through a cirrus cloud. Because of slower $\mathrm{MCH}$ sensor response at colder sensor temperatures, the $\mathrm{MCH} \mathrm{RH}_{\text {liquid }}$ values can not follow the rapid changes in $\mathrm{RH}_{\text {liquid }}$ as observed by the reference.

- Sequence 3 refers to a section of the flight between 11:00 and 11:40 UTC, when $T_{\text {sensor }}$ reaches values below the sensor calibration limit of $T_{\text {sensor }}=-40^{\circ} \mathrm{C}$, i.e. ambient temperatures below $-70^{\circ} \mathrm{C}$ at commercial air- 
Table 4. Median, 25th/75th percentile values and counts of $\triangle \mathrm{RH}_{\text {liquid }}\left(\mathrm{MCH}\right.$ and reference). Data were classified into $5 \% \mathrm{RH}_{\text {liquid }}$ bins relating to the reference, i.e. OJSTER data in cloud or otherwise FISH data.

\begin{tabular}{lccccccccc}
\hline $\mathrm{RH}$ bin & $0-5 \%$ & $5-10 \%$ & $10-15 \%$ & $15-20 \%$ & $20-25 \%$ & $25-30 \%$ & $30-35 \%$ & $35-40 \%$ & $40-45 \%$ \\
\hline $\begin{array}{l}\Delta \mathrm{RH} \mathrm{H}_{\text {liquid }} \\
{[\% \mathrm{RH}]}\end{array}$ & - & $3.0_{-0.4}^{+0.2}$ & $1.0_{-1.1}^{+1.6}$ & $0.4_{-2.9}^{+2.2}$ & $-1.8_{-2.7}^{+2.4}$ & $-2.3_{-2.8}^{+5.5}$ & $-0.1_{-4.4}^{+5.2}$ & $3.7_{-7.3}^{+3.4}$ & $3.9_{-2.9}^{+4.2}$ \\
Counts [\#] & - & 13 & 1276 & 4037 & 2335 & 1471 & 1606 & 776 & 569 \\
\hline $\mathrm{RH}$ bin & $45-50 \%$ & $50-55 \%$ & $55-60 \%$ & $60-65 \%$ & $65-70 \%$ & $70-75 \%$ & $75-80 \%$ & $80-85 \%$ & $85-90 \%$ \\
\hline $\begin{array}{l}\Delta \mathrm{RH}_{\text {liquid }} \\
{[\% \mathrm{RH}]}\end{array}$ & $5.4_{-3.1}^{+3.5}$ & $4.2_{-2.9}^{+2.6}$ & $1.7_{-4.2}^{+3.8}$ & $0.4_{-2.8}^{+3.7}$ & $-0.8_{-3.3}^{+2.7}$ & $-3.3_{-2.8}^{+2.9}$ & $-7.7_{-4.0}^{+3.8}$ & $-12.3_{-7.1}^{+3.8}$ & $-8.9_{-0.8}^{+0.8}$ \\
$\begin{array}{l}\text { Counts [\#] } \\
813\end{array}$ & 2015 & 2910 & 2567 & 1109 & 512 & 148 & 24 & 3 \\
\hline
\end{tabular}
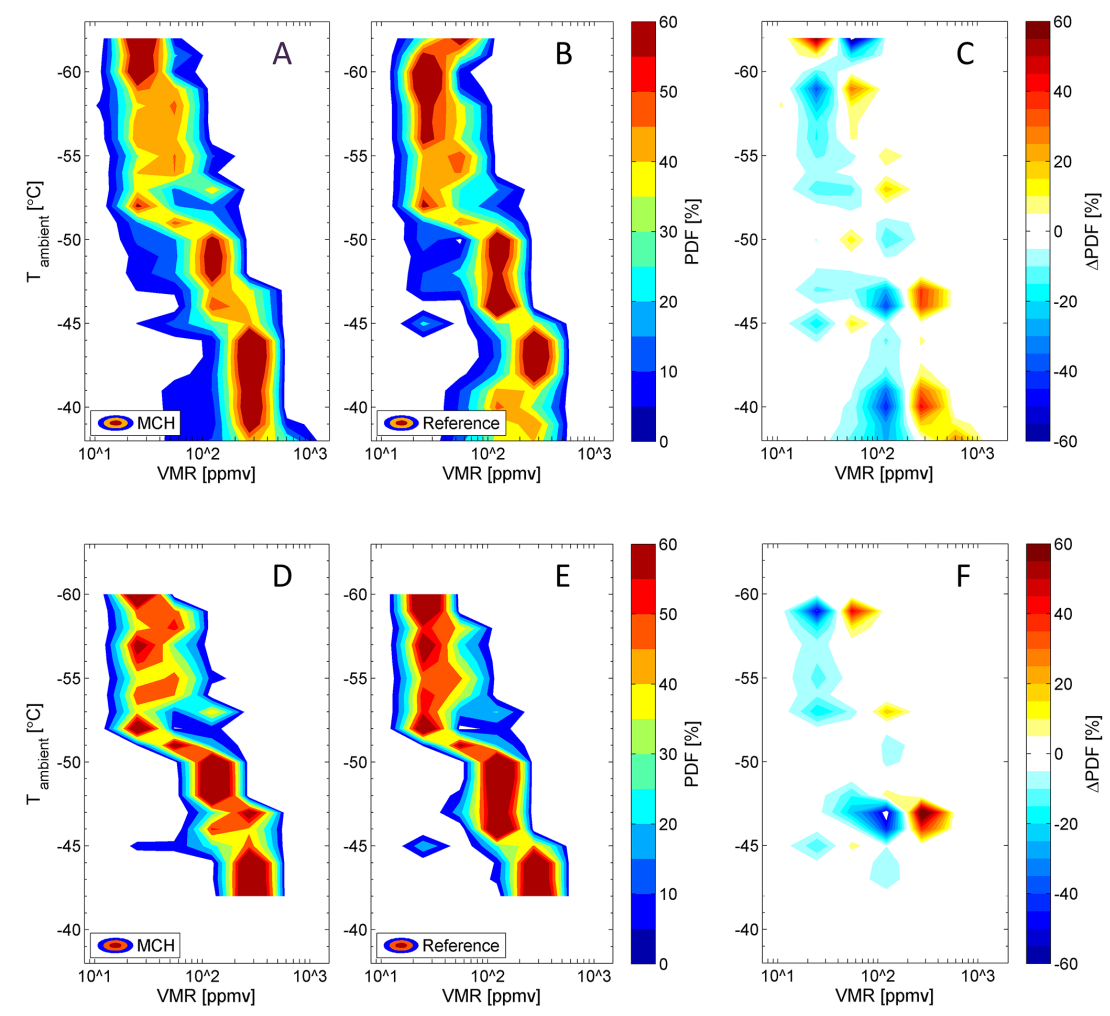

Figure 12. Probability density functions (PDFs) of the complete (a-c) and reduced (d-f) $\mathrm{MCH}(\mathbf{a}$, d) and reference (b, e), i.e. FISH (clear sky) and OJSTER (in-cirrus), water vapour volume mixing ratio (VMR) data related to the ambient temperature $T_{\text {ambient }}$. Water vapour volume mixing ratio is binned in the logarithmic space between 0 and 8.8 , with a bin size of 0.8 and temperature in $1^{\circ} \mathrm{C}$ bins. (c) and (f) show the difference of the $\mathrm{MCH}$ and reference PDFs for the complete and reduced data set, respectively.

craft speed of $M=0.81$. The MCH shows an increased response time and a loss of signal fine structure, and increasing deviations between the $\mathrm{MCH}$ and the reference instruments occur.

Despite delayed sensor response for conditions at the limit of its operation range, the $\mathrm{MCH}$ shows a very good overall performance during the CIRRUS-III field study. Figure 12 illustrates the PDFs of water vapour VMR data as a function of $T_{\text {ambient }}$ (panels a to c for the complete data set and panels $\mathrm{d}$ to $\mathrm{f}$ for the reduced data set) according to Kunz et al.
(2008). The frequencies of occurrence are calculated in $1^{\circ} \mathrm{C}$ bins for the $\mathrm{MCH}$ data set (panels a and d), the reference data set (panels b and e) and the deviation of the $\mathrm{MCH}$ and reference PDFs for the complete and reduced data set (panel c and $\mathrm{f}$ ). The water vapour VMR is binned in the logarithmic space between 0.0 and 8.0 with a bin size of 0.8 . The colour bars are binned in $5 \%$ spaces for a better interpretation of the contour plots.

The MCH seems to remain at dryer values for the coldest temperatures of $T_{\text {ambient }} \cong-60{ }^{\circ} \mathrm{C}$, which is again a result of 
the delayed sensor response at sensor temperatures below the calibration limit. Further, small deviations at lower temperatures are also observed. In summary, data sets for both cases show a similar behaviour in the water vapour VMR distribution with only small deviations; these deviations have no statistically significant relevance.

\section{Conclusions and recommendations}

The CIRRUS-III (2006) aircraft campaign provided a data set for the evaluation of the MOZAIC Capacitive Hygrometer in a blind intercomparison with high-performance water vapour instruments based on tunable diode laser absorption spectrometry (OJSTER, in-cloud reference) and Lyman$\alpha$ fluorescence detection (FISH, clear-sky reference).

Except for conditions at its operation limit (e.g. $T_{\text {sensor }}<-40^{\circ} \mathrm{C}$ and during rapid changes in $\mathrm{RH}_{\text {liquid }}$ ), the $\mathrm{MCH}$ performs with a difference of $10 \% \mathrm{RH}_{\text {liquid }}$ or less to the references.

In order to obtain a representative result for the MCH's uncertainty for its regular deployment aboard passenger aircraft, the data set was restricted to conditions corresponding to regular sensor operation aboard MOZAIC aircraft: data with sensor temperatures below $-40{ }^{\circ} \mathrm{C}$ were excluded due to the calibration limit. In MOZAIC less than $1 \%$ of $\mathrm{RH}$ observations are made at sensor temperatures colder than $-40^{\circ} \mathrm{C}$. Strong ascent and descent sequences of the aircraft were removed, and the maximum $T_{\text {ambient }}$ was set to $-40^{\circ} \mathrm{C}$ to exclude effects of warm clouds.

The $1 \mathrm{~Hz}$ correlation yielded a robust linear fit with a slope of unity, with no statistically significant offset and a correlation coefficient of $R^{2}=0.92$, which was confirmed by the correlation of the binned $\mathrm{RH}_{\text {liquid }}$ data. The $\mathrm{RH}_{\text {liquid }}$ data grouped in $5 \% \mathrm{RH}_{\text {liquid }}$ bins agree very well for the $\mathrm{MCH}$ and reference instruments over the entire cloud-free range and for most of the cirrus cloud sequences, and they yield a $\mathrm{MCH}$ uncertainty of $5 \% \mathrm{RH}_{\text {liquid. }}$.

Comparing the MCH's and references' PDFs for $\mathrm{RH}_{\text {liquid }}$ shows no statistically significant effect of delayed sensor response at conditions beyond the operation range. Neither strong humidity changes nor operation at the lower calibration limits causes considerable sensor failures. The main limitation for the use of $\mathrm{MCH} \mathrm{RH}_{\text {liquid }}$ data is related to sensor temperatures below the calibration limit of $T_{\text {sensor }}=-40^{\circ} \mathrm{C}$. However, these temperatures are encountered only rarely in the MOZAIC programme as long as the flight routes do not reach polar air masses with ambient temperatures below $-70^{\circ} \mathrm{C}$. In summary, the $\mathrm{MCH}$ is highly suitable for climatology analyses in the MOZAIC programme even if the sensor is not applicable to high-time-resolution measurements.

A value for the limit of detection is not appropriate for the $\mathrm{MCH}$, but the variable to describe its performance is the here determined uncertainty of the $\mathrm{RH}_{\text {liquid }}$ measurements. $\mathrm{RH}_{\text {liquid }}$ measurements below $5 \%$, which are common in the lowermost stratosphere, have to be used carefully because these data are close to the sensor uncertainty range, which, as shown before in Sect. 4.1, results in a relative deviation of $100 \%$.

Acknowledgements. The authors gratefully acknowledge Peter Spichtinger (Mainz Univ.) for fruitful discussions. The support by enviscope $\mathrm{GmbH}$ to the technical organisation of the field study is also appreciated. Part of this work was funded by the German Federal Ministry for Research and Education (BMBF) in the framework of the joint programme IAGOS-D under grant no. 01LK1223A.

The service charges for this open-access publication have been covered by a Research Centre of the Helmholtz Association.

Edited by: S. Malinowski

\section{References}

Bange, J., Esposito, M., Lenschow, D. H., Brown, P. R. A., Dreiling, V., Giez, A., Mahrt, L., Malinowski, S. P., Rodi, A. R., Shaw, R. A., Siebert, H., and Smit, H. G. J., and Zöger, M.: Measurement of Aircraft State and Thermodynamic and Dynamic Variables, in: Airborne Measurements for Environmental Research: Methods and Instruments, edited by: Wendisch, M., and Brenguier, J.-L., Wiley Online Library, doi:10.1002/9783527653218.ch2, 2013.

Gierens, K., Schumann, U., Helten, M., Smit, H., and Marenco, A.: A distribution law for relative humidity in the upper troposphere and lower stratosphere derived from three years of MOZAIC measurements, Ann. Geophys., 17, 1218-1226, doi:10.1007/s00585-999-1218-7, 1999.

Gierens, K., Schumann, U., Helten, M., Smit, H., and Wang, P.: Ice-supersaturated regions and subvisible cirrus in the northern midlatitude upper troposphere, J. Geophys. Res., 105, 2274322753, doi:10.1029/2000JD900341, 2000.

Gierens, K. M., Schumann, U., Smit, H. G. J., Helten, M., and Zängl, G.: Determination of humidity and temperature fluctuations based on MOZAIC data and parametrisation of persistent contrail coverage for general circulation models, Ann. Geophys., 15, 1057-1066, doi:10.1007/s00585-997-1057-3, 1997.

Goff, J. A. and Gratch, S.: Low-pressure properties of water from160 to 212 F, Trans. Amer. Soc. Heat. Vent. Eng, 52, 95-121, 1946.

Helten, M., Smit, H., Sträter, W., Kley, D., Nedelec, P., Zöger, M., and Busen, R.: Calibration and performance of automatic compact instrumentation for the measurement of relative humidity from passenger aircraft, J. Geophys. Res., 103, 25643-25652, doi:10.1029/98JD00536, 1998.

Helten, M., Smit, H., Kley, D., Ovarlez, J., Schlager, H., Baumann, R., Schumann, U., Nedelec, P., and Marenco, A.: In-flight comparison of MOZAIC and POLINAT water vapor measurements, J. Geophys. Res., 104, 26087-26096, doi:10.1029/1999JD900315, 1999.

IPCC: Climate Change 2013: The Physical Science Basis. Contribution of Working Group I to the Fifth Assessment Report of the 
Intergovernmental Panel on Climate Change, edited by: Stocker, T. F., Qin, D., Plattner, G.-K., Tignor, M., Allen, S. K., Boschung, J., Nauels, A., Xia, Y., Bex, V., and Midgley, P. M., Cambridge University Press, Cambridge, United Kingdom and New York, NY, USA, 1535 pp., doi:10.1017/CBO9781107415324, 2013.

Kley, D. and Stone, E.: Measurement of water-vapor in the stratosphere by photo-dissociation with Ly-alpha (1216 A) light, Rev. Sci. Instrum., 49, 691-697, doi:10.1063/1.1135596, 1978.

Kley, D., Smit, H. G. J., Nawrath, S., Luo, Z., Nedelec, P., and Johnson, R. H.: Tropical Atlantic convection as revealed by ozone and relative humidity measurements, J. Geophys. Res., 112, doi:10.1029/2007JD008599, 2007.

Krämer, M., Schiller, C., Afchine, A., Bauer, R., Gensch, I., Mangold, A., Schlicht, S., Spelten, N., Sitnikov, N., Borrmann, S., de Reus, M., and Spichtinger, P.: Ice supersaturations and cirrus cloud crystal numbers, Atmos. Chem. Phys., 9, 3505-3522, doi:10.5194/acp-9-3505-2009, 2009.

Kunz, A., Schiller, C., Rohrer, F., Smit, H. G. J., Nedelec, P., and Spelten, N.: Statistical analysis of water vapour and ozone in the UT/LS observed during SPURT and MOZAIC, Atmos. Chem. Phys., 8, 6603-6615, doi:10.5194/acp-8-6603-2008, 2008.

Luo, Z., Kley, D., Johnson, R. H., and Smit, H.: Ten years of measurements of tropical upper-tropospheric water vapor by MOZAIC. Part I: Climatology, variability, transport, and relation to deep convection, J. Climate, 20, 418-435, doi:10.1175/JCLI3997.1, 2007.

Luo, Z., Kley, D., Johnson, R. H., and Smit, H.: Ten years of measurements of tropical upper-tropospheric water vapor by MOZAIC. Part II: Assessing the ECMWF humidity analysis, J. Climate, 21, 1449-1466, doi:10.1175/2007JCLI1887.1, 2008.

Marenco, A., Thouret, V., Nedelec, P., Smit, H., Helten, M., Kley, D., Karcher, F., Simon, P., Law, K., Pyle, J., Poschmann, G., von Wrede, R., Hume, C., and Cook, T.: Measurement of ozone and water vapor by Airbus in-service aircraft: The MOZAIC airborne program, An overview, J. Geophys. Res., 103, 25631-25642, doi:10.1029/98JD00977, 1998.

May, R. and Webster, C.: Data processing and calibration for tunable diode-laser harmonic absorption spectrometers, J. Quant. Spectrosc. Ra., 49, 335-347, doi:10.1016/0022-4073(93)900983, 1993.

Mottaghy, D.: Ozonmessungen in der unteren Stratosphäre, Master thesis, Rheinisch-Westfälische Technische Hochschule Aachen, in cooperation with the Institute for Chemistry and Dynamics of the Geosphere, ICG-1: Stratosphere, 2001.

Petzold, A., Volz-Thomas, A., Thouret, V., Cammas, J.-P., and Brenninkmeijer, C.: IAGOS - In-service Aircraft for a Global Observing System, in: 3rd International Conferene on Transport, Atmosphere and Climate, Germany, 25-28 June 2012, 69-76, 2013.
Schlager, H., Konopka, P., Schulte, P., Schumann, U., Ziereis, H., Arnold, F., Klemm, M., Hagen, D., Whitefield, P., and Ovarlez, J.: In situ observations of air traffic emission signatures in the North Atlantic flight corridor, J. Geophys. Res., 102, 10739 10750, doi:10.1029/96JD03748, 1997.

Schumann, U.: Pollution from aircraft emissions in the North Atlantic flight corridor (POLINAT), Air Pollut. Res. Rep. 58, Rep. EUR 16978 EN, Europ. Commission, Luxembourg, 1997.

Smit, H., Sträter, W., Helten, M., and Kley, D.: Environmental Simulation Facility to Calibrate Airborne Ozone and Humidity Sensors, Tech. rep., Berichte des Forschungszentrums Jülich; Report No. 3796, 2000.

Smit, H. G. J., Volz-Thomas, A., Helten, M., Paetz, W., and Kley, D.: An in-flight calibration method for near-real-time humidity measurements with the airborne MOZAIC sensor, J. Atmos. Ocean. Tech., 25, 656-666, doi:10.1175/2007JTECHA975.1, 2008.

Smit, H. G. J., Rohs, S., Neis, P., Boulanger, D., Krämer, M., Wahner, A., and Petzold, A.: Technical Note: Reanalysis of upper troposphere humidity data from the MOZAIC programme for the period 1994 to 2009, Atmos. Chem. Phys., 14, 13241-13255, doi:10.5194/acp-14-13241-2014, 2014.

Sonntag, D.: Advancements in the field of hygrometry, Meteorol. Z., 3, 51-66, 1994.

Spichtinger, P., Gierens, K., Leiterer, U., and Dier, H.: Ice supersaturation in the tropopause region over Lindenberg, Germany, Meteorol. Z., 12, 143-156, doi:10.1127/0941-2948/2003/00120143, 2003.

Stickney, T. M., Shedlov, M., and Thompson, D. I.: Rosemount total temperature sensors, Tech. rep., 5755, Revision B, Aerosp. Div. Rosemount Inc., 1990.

WMO: Measurement of atmospheric humidity. Guide to Meteorological Instruments and Methods of Observation, Tech. rep., 5th Edn. WMO Rep. 8, 5.1-5.19, 1983.

Zöger, M., Afchine, A., Eicke, N., Gerhards, M., Klein, E., McKenna, D., Morschel, U., Schmidt, U., Tan, V., Tuitjer, F., Woyke, T., and Schiller, C.: Fast in situ stratospheric hygrometers: A new family of balloon-borne and airborne Lyman alpha photofragment fluorescence hygrometers, J. Geophys. Res., 104, 1807-1816, doi:10.1029/1998JD100025, 1999. 